\title{
A New Class of Semisynthetic Anthracycline Glycoside Antibiotics Incorporating a Squaric Acid Moiety
}

\author{
Ferenc Sztaricskai, Anita Sum, Erzsébet Roth, István F. Pelyvás, Szabolcs Sándor, \\ Gyula Batta, Pál Herczegh, Judit Reményi, Zsanett Miklán, Ferenc Hudecz
}

Received: July 19, 2005 / Accepted: November 2, 2005

(C) Japan Antibiotics Research Association

\begin{abstract}
Treatment of the squaric acid amide esters (7, 9) of anthracycline glycoside antibiotics with aliphatic and aromatic primary and secondary amines, amino acids, peptides and aminodeoxy sugars furnished the new asymmetric diamides $16 \sim 19,25 \sim 30,32,34$ and $38 \sim 40$ in stereoselective reactions which do not require protecting group-manipulations. The $\mathrm{IC}_{50}=0.12 \mu \mathrm{M}$ value measured for daunorubicin (1) on human leukemia (HL-60) cells is comparable to those obtained for the daunomycin-L-leucyl squaric acid diamide $\left(\mathbf{3 0}, \quad \mathrm{IC}_{50}=0.18 \mu \mathrm{M}\right)$ and the corresponding D-galactosamine derivative $\left(\mathbf{4 0}, \mathrm{IC}_{50}=0.22\right.$ $\mu \mathrm{M})$.
\end{abstract}

Keywords anthracycline glycoside antibiotics, squaric acid amides, HL-60 activity

\section{Introduction}

The anthracycline glycoside antibiotics $(\mathbf{1} \sim \mathbf{3})$ are extremely significant and useful agents in antitumor chemotherapy. To reduce or avoid their cardiotoxic sideeffect many semisynthetic derivatives have been prepared, and the most important representatives are those modified at the aminodeoxy sugar moiety (L-daunosamine). Extensive studies have been carried out to determine the influence of the configuration of the aminodeoxy sugar unit $(\mathrm{L}-l y x o>\mathrm{L}-$ arabino $>\mathrm{L}-r i b o>\mathrm{L}-x y l o)$ [1 3], its substituents [4 8] and ring-size [9] on the DNA-affinity, antitumor activity and cardiotoxicity of the new (stereo)isomers.

By the acylation [10], alkylation [11], and formation of an enamino analogue [12] at the C-3' primary amino group, as well as incorporation of this latter moiety into various heterocyclic rings (morpholine [13,14], oxazoline [15], triazole [16], etc.) a huge number of semisynthetic antibiotics have been synthesized. Replacement of the $\alpha$-Ldaunosaminyl unit with L-acosamine (with L-arabino configuration) epirubicin (4) was obtained, which was introduced into chemotherapy. Of the amino-acyl and heterocyclic analogues, $N$-L-leucyl-adriamycin (5) [10] and 3'-deamino-3'-morpholinyl-pirarubicin (6) [11], respectively, possess the most significant antitumor effect (Fig. 1).

In a recent work, Sztaricskai and coworkers have successfully applied squaric acid esters, introduced to organic chemistry by Tietze et al. [17], for the chemical synthesis [18] of the squaric acid amide esters (7 9) and the corresponding covalent dimers $(\mathbf{1 0} \sim \mathbf{1 3})$ of the anthracycline glycoside antibiotics $\mathbf{1} \sim \mathbf{3}$ (Fig. 2).

In this paper an extension of our previous work is described, which is aimed at the synthesis of new, asymmetric diamide derivatives, and investigation of their effect on human leukemia (HL-60) cells.
F. Sztaricskai (Corresponding author), A. Sum, E. Roth, I. F. Pelyvás, S. Sándor, G. Batta, P. Herczegh: Research Group for Antibiotics of the Hungarian Academy of Sciences, and Department of Pharmaceutial Chemistry, University of Debrecen, H-4010 Debrecen, P. O. Box 70, Hungary.

E-mail: sztarife@delfin.klte.hu
J. Reményi, Z. Miklán, F. Hudecz: Research Group for Peptide Chemistry, Hungarian Academy of Sciences and Department of Organic Chemistry, Eötvös Lóránd University, H-1518 Budapest, P. O. Box 32, Hungary 


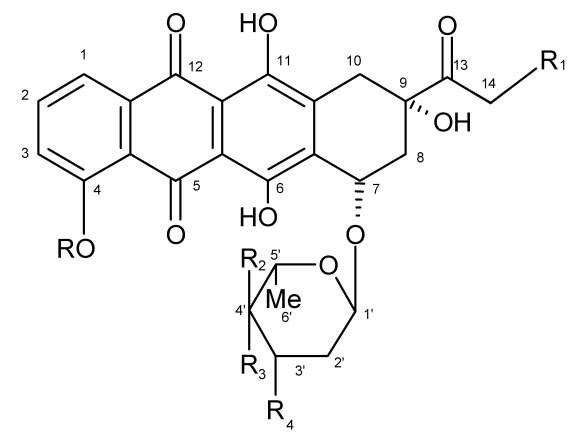

$\mathrm{R}=\mathrm{Me}, \mathrm{R}_{1}=\mathrm{R}_{2}=\mathrm{H}, \mathrm{R}_{3}=\mathrm{OH}, \mathrm{R}_{4}=\mathrm{NH}_{2}$
$\mathrm{R}=\mathrm{Me}, \mathrm{R}_{1}=\mathrm{R}_{3}=\mathrm{OH}, \mathrm{R}_{2}=\mathrm{H}, \mathrm{R}_{4}=\mathrm{NH}_{2}$
$\mathrm{R}=\mathrm{R}_{1}=\mathrm{R}_{2}=\mathrm{H}, \mathrm{R}_{3}=\mathrm{OH}, \mathrm{R}_{4}=\mathrm{NH}_{2}$
$\mathrm{R}=\mathrm{Me}, \mathrm{R}_{1}=\mathrm{R}_{2}=\mathrm{OH}, \mathrm{R}_{3}=\mathrm{H}, \mathrm{R}_{4}=\mathrm{NH}_{2}$
$\mathrm{R}=\mathrm{Me}, \mathrm{R}_{1}=\mathrm{R}_{3}=\mathrm{OH}, \mathrm{R}_{2}=\mathrm{H}, \mathrm{R}_{4}=-\mathrm{NH}$

$\mathrm{R}=\mathrm{Me}, \mathrm{R}_{1}=\mathrm{OH}, \mathrm{R}_{2}=\mathrm{H}$<smiles>[R][C-]1CCC[C@@H](OC)OC1</smiles>

$$
\begin{array}{ll}
\text { 7: } & R=M e, R_{1}=R_{2}=H, R_{3}=O H \\
\text { 8: } & R=M e, R_{1}=R_{3}=O H, R_{2}=H \\
\text { 9: } & R=R_{1}=R_{2}=H, R_{3}=O H
\end{array}
$$
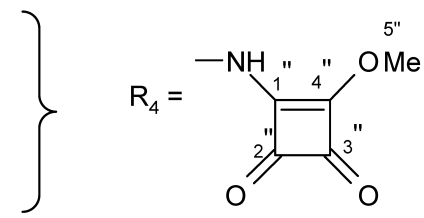

Fig. 1 Important representatives of the anthracycline glycoside antibiotics.

\section{Results and Discussion}

The reaction of the squaric acid amide esters (7 and 9) of daunomycin and carminomycin, respectively, with 4phenylbenzylamine (14) was rather sluggish, whereas with 6-amino-1-hexanol (15) it was much faster to furnish the asymmetric diamides 16 19 with good yields in each case (Scheme 1). Introduction of the aromatic or aliphatic sidechains greatly enhanced the lipoid-solubility of these semisynthetic antibiotic molecules. The physico-chemical properties and ${ }^{1} \mathrm{H}$ - and ${ }^{13} \mathrm{C}$-NMR data of the synthesized new compounds are presented in Tables 1, 2 and 3, respectively.

The advantageous pharmacological properties of the $\mathrm{N}$ - leucyl derivative (5, Leurubicin ${ }^{\circledR}$ [10]) of adriamycin, introduced earlier, prompted us to perform modification of daunomycin also with this amino acid involving squaric acid. Thus, direct condensation of the squaric acid amide ester 7 with the amino acids 20 and 24, and with the peptides 21 23, and also the similar ester 9 with triglycine gave the new semisynthetic antibiotics 25 30 (Scheme 1). The pure products could be isolated with excellent yields by means of column chromatography. The desired amides with triglycine formed with practically the same yield from daunomycin and carminomycin, indicating that the presence of the free phenolic hydroxyl group, or its substitution with a methyl group do not influence the reaction. Tables 1 and 4 contain the molar masses determined with MALDI-TOF and the ${ }^{1} \mathrm{H}$ - and ${ }^{13} \mathrm{C}-\mathrm{NMR}$ 


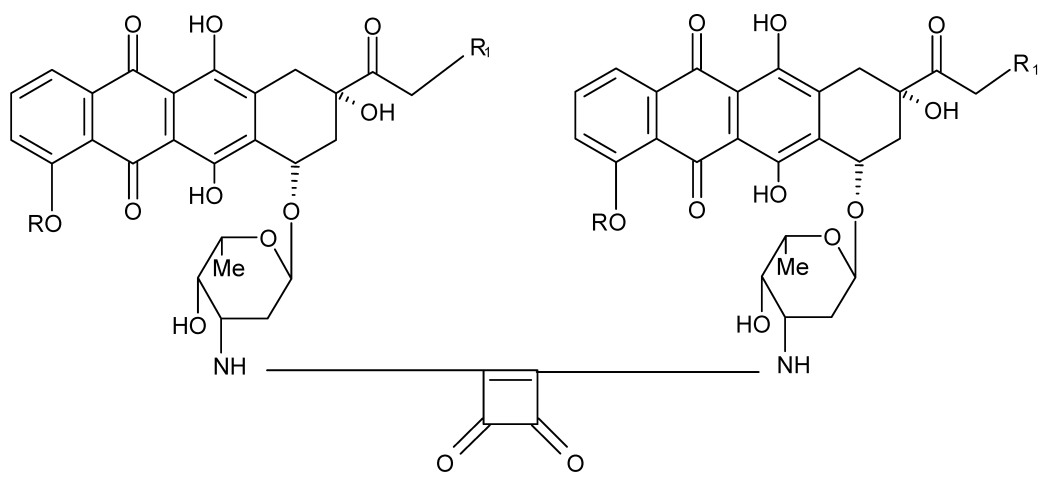

10: $R=M e, R_{1}=H$

11: $\mathrm{R}=\mathrm{Me}, \mathrm{R}_{1}=\mathrm{OH}$

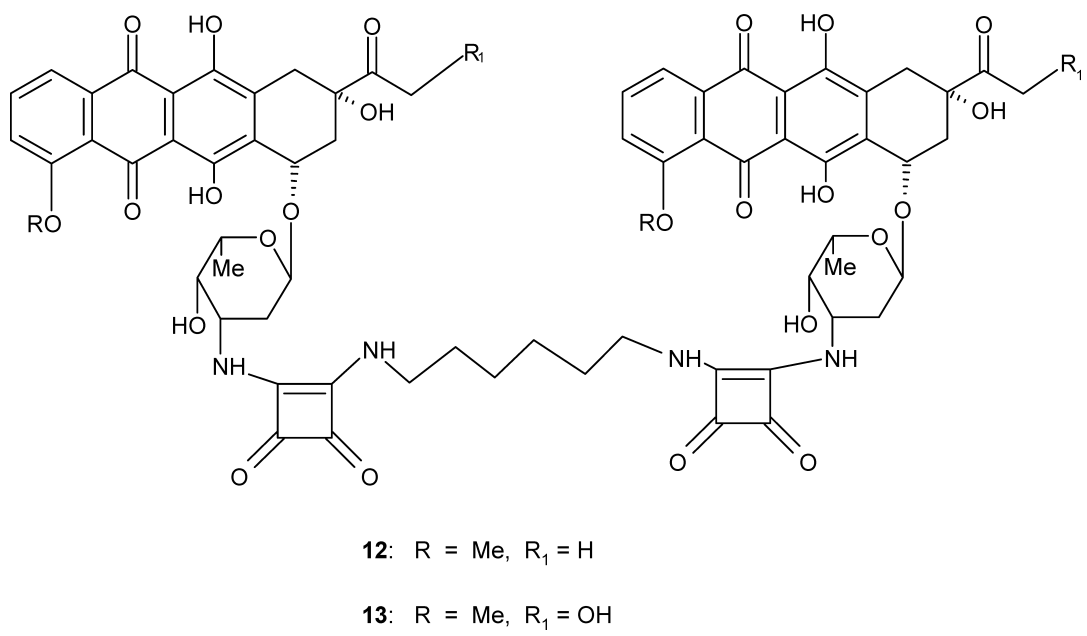

Fig. 2 Covalent dimers of the anthracycline glycoside antibiotics.

data, respectively, which substantiate the structures of the products.

Reports in the literature indicate that the $\mathrm{N}$-morpholinyl derivatives of the anthracycline glycosides (6, pirarubicin) [11] are more efficient antitumor agents than the parent antibiotics, and the piperazine-compounds are essential building components of numerous drug-molecules. These encouraged us to prepare the asymmetric diamides $\mathbf{3 2}$ and 34 (Scheme 2) by treatment of the daunomycin squaric acid amide ester (7) with morpholine (31) and 1benzylpiperazine (33). Although the reaction times with these secondary amines were longer, the desired semisynthetic antibiotics could be obtained with $77 \sim 79 \%$ yield (see Tables 1 and 5).

It is well-known that the various squaric acid derivatives possess low solubility in water [17]. However, introduction of carbohydrate moieties would enhance the watersolubility and decrease the disadvantageous toxic effects.

The reaction of 7 with D-glucosylamine (35) and Dglucosamine (36) at room temperature for 5 days resulted in 38 and 39, and the same reaction with D-galactosamine (37), to give 40, required 10 days (Scheme 2). Following column chromatographic purification, $\mathbf{3 8}$ and $\mathbf{3 9}$ were obtained with low and moderate yield, respectively, but the yield for $\mathbf{4 0}$ was excellent. The physico-chemical properties and the ${ }^{1} \mathrm{H}$ - and ${ }^{13} \mathrm{C}$-NMR data for the antibiotic analogues 38 $\sim 40$ are collected in Tables 1 and 6, respectively.

As expected, the solubility of the products in water was enhanced: while $1.0 \mathrm{mg}$ of the squaric acid amide ester of daunomycin (7) dissolved only in a $1: 1(\mathrm{v} / \mathrm{v})$ DMSO-water 


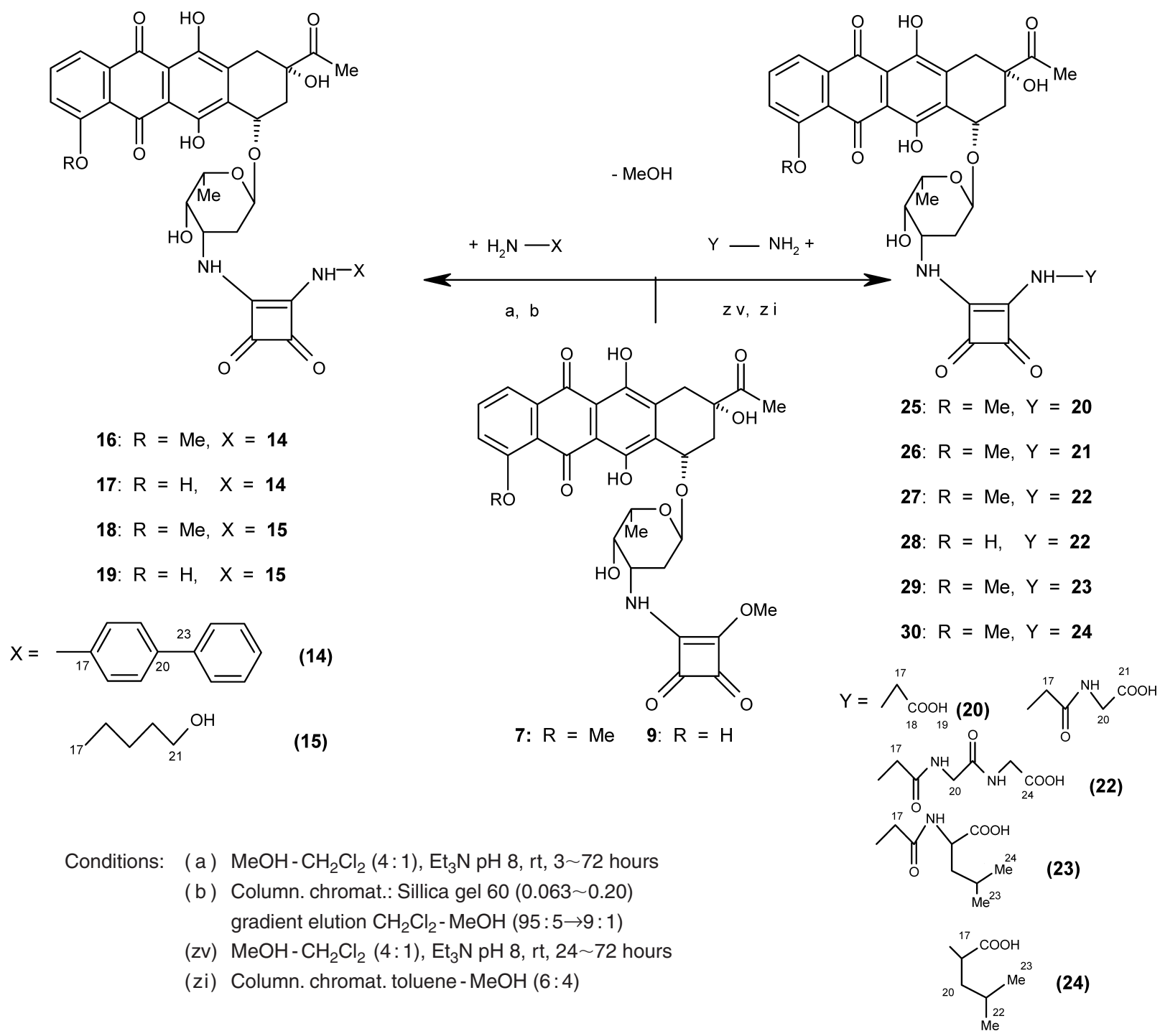

Scheme 1 Reactions of squaric acid amide esters of anthracycline antibiotics with primary amines, amino acids and peptides.

mixture $(0.5 \mathrm{ml})$, the same amount of $\mathbf{3 8} \sim \mathbf{4 0}$ was soluble in $0.5 \mathrm{ml}$ of water.

\section{In Vitro Antitumour Effect and Discussion}

The results of the in vitro antitumor effect of the prepared new semisynthetic antibiotics on human leukemia 60 (HL60) cells are summarized in Table 7. Comparison of the $\mathrm{IC}_{50}$ values obtained for the asymmetric diamides derived from daunomycin and carminomycin with 4-phenylbenzylamine and 6-amino-1-hexanol shows that the carminomycin derivatives $\mathbf{1 7}$ and $\mathbf{1 9}$ are active in a concentration of one order of magnitude lower than the corresponding daunomycin analogues (16 and 18). The most active molecule is the daunomycin-L-leucyl-squaric diamide (30) possessing an $\mathrm{IC}_{50}$ value of $0.18 \mu \mathrm{M}$, which is very close to that $(0.12 \mu \mathrm{M})$ measured for daunomycin (daunorubicin) introduced to clinical cancer chemotherapy. When an L-leucylglycine dipeptide unit was attached to daunomycin through a squaric acid molecule, the activity of the substance (29) decreased by more than one order of magnitude, and very similar results were observed for the daunomycin-diglycyl squaric acid diamide $\mathbf{2 6}$.

The difference between the biological activities of the squaric acid diamides $\mathbf{2 7}$ and $\mathbf{2 8}$ of daunomycin and carminomycin, incorporating the triglycine unit, is rather surprising: the latter derivative is more effective. Biological studies [18] of the previously prepared covalent dimers, derived from carminomycin and another anthracycline 


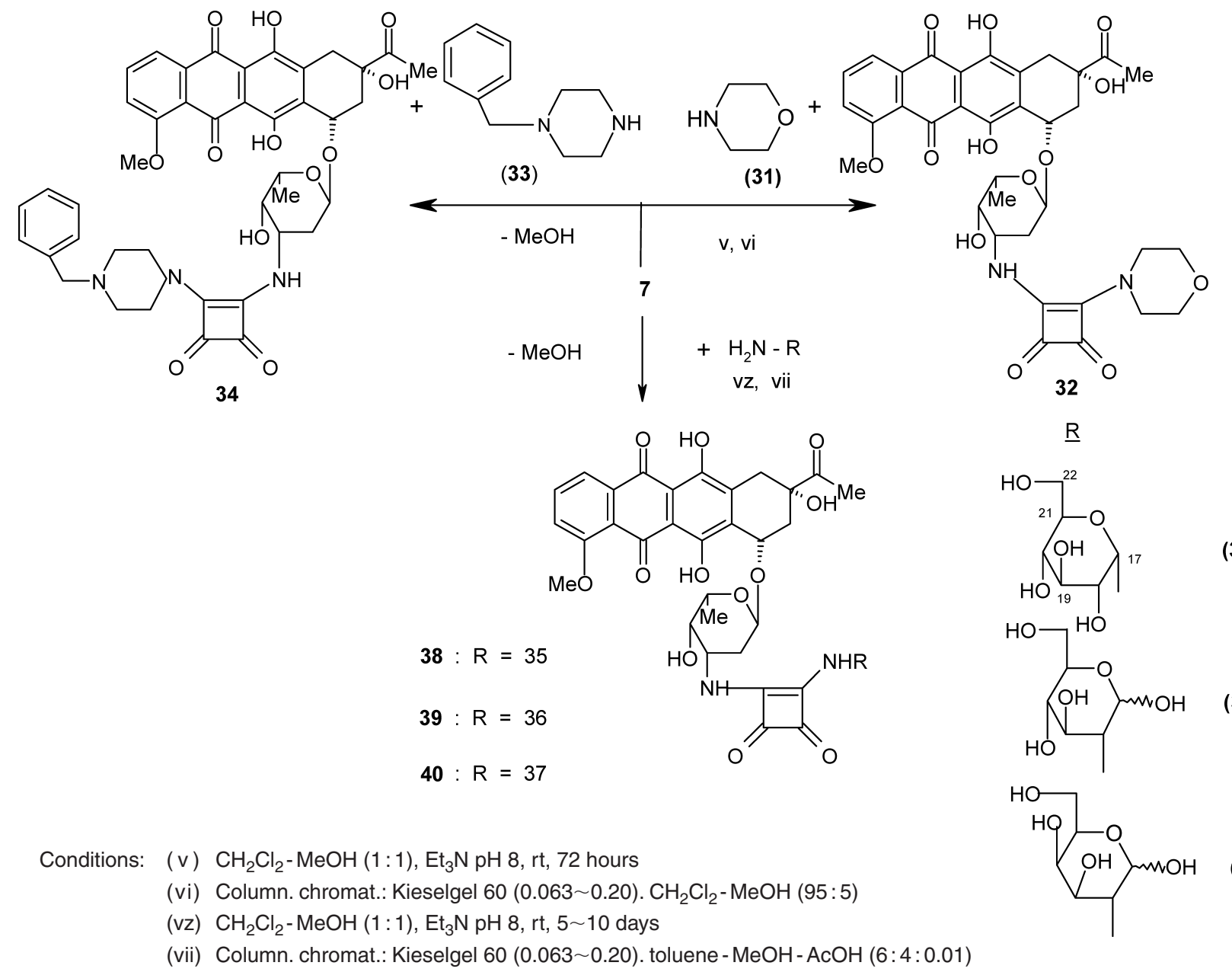

(35)

(36)

(37)

Scheme 2 Reactions of squaric acid amide esters of anthracycline antibiotics with secondary amines and aminodeoxy sugars.

glycoside antibiotics, gave similar results. At the same time, the activity of the daunomycin-morpholinyl squaric acid diamide (32) is one order of magnitude lower than that of the $\mathrm{N}$-benzylpiperazinyl derivative $\mathbf{3 4}$. Of the substances synthesized by the application of aminodeoxy sugars, the $\mathrm{IC}_{50}$ value $(0.22 \mu \mathrm{M})$ measured for the daunomycin-Dgalactosamine squaric acid diamide (40) is the most outstanding. Compared to this compound (40), $\mathbf{3 8}$ and $\mathbf{3 9}$ were found active on HL-60 cells only in three times higher concentration, and this difference can only be explained by the opposite configuration at carbon C-4 of D-glucosamine (36) and D-galactosamine (37).

\section{Experimental}

The solutions were evaporated under diminished pressure at $35 \sim 37^{\circ} \mathrm{C}$ on a Büchi R-114 rotary evaporator. For monitoring of the reactions, and homogenity check TLC and HPLC were used. Related, and the UV spectral and MALDI-TOF data are presented in Table 1. For NMR spectroscopy, a Bruker DRX-500 instrument operating at $500.13 \mathrm{MHz}$ and $125.79 \mathrm{MHz}$ frequencies, respectively, for the ${ }^{1} \mathrm{H}$ and ${ }^{13} \mathrm{C}$ nuclei was used (see Tables $2 \sim 6$ ). Internal TMS was the reference material. Tipically, ${ }^{1} \mathrm{H},{ }^{13} \mathrm{C}$, and $2 \mathrm{D}$ COSY and HSQC spectra were recorded for assignment, sometimes augmented with TOCSY and HBMC spectra. 
Table 1 Physico-chemical properties of the squaric acid asymmetric diamides of the anthracycline antibiotics

\begin{tabular}{|c|c|c|c|c|c|c|c|}
\hline \multirow[b]{2}{*}{$\begin{array}{c}\text { Asymmetric diamides } \\
\text { of squaric acid }\end{array}$} & \multirow[b]{2}{*}{$\begin{array}{l}\text { Yied } \\
(\%)\end{array}$} & \multirow[b]{2}{*}{$\begin{array}{l}\mathrm{HPLC} \\
\mathrm{R}_{\mathrm{T}}\end{array}$} & \multirow[b]{2}{*}{$\begin{array}{c}\text { TLC } \\
\mathrm{Rf}\end{array}$} & \multirow[b]{2}{*}{$\begin{array}{l}\text { Formula of } \\
\text { compounds }\end{array}$} & \multicolumn{2}{|c|}{ Molecular weight } & \multirow[b]{2}{*}{$\begin{array}{l}\text { UV } \lambda_{\max } \mathrm{nm} \\
\text { (DMSO) }\end{array}$} \\
\hline & & & & & Calculated & $\begin{array}{c}\text { Measured } \\
\text { MALDI-TOF } \\
(\mathrm{M}+\mathrm{Na})^{+}\end{array}$ & \\
\hline 16 & 61.8 & 22.87 & (1) 0.40 & $\mathrm{C}_{44} \mathrm{H}_{40} \mathrm{~N}_{2} \mathrm{O}_{12}$ & 788.78 & 811.46 & 295 \\
\hline 17 & 65.8 & 24.10 & (1) 0.17 & $\mathrm{C}_{43} \mathrm{H}_{38} \mathrm{~N}_{2} \mathrm{O}_{12}$ & 774.45 & 797.42 & 258 \\
\hline 18 & 73.0 & 17.22 & (1) 0.40 & $\mathrm{C}_{37} \mathrm{H}_{42} \mathrm{~N}_{2} \mathrm{O}_{13}$ & 722.73 & 745.47 & 294 \\
\hline 19 & 69.8 & 18.39 & (1) 0.20 & $\mathrm{C}_{36} \mathrm{H}_{40} \mathrm{~N}_{2} \mathrm{O}_{17}$ & 708.70 & 731.43 & 296 \\
\hline 25 & 95.8 & 16.07 & (2) 0.15 & $\mathrm{C}_{33} \mathrm{H}_{32} \mathrm{~N}_{2} \mathrm{O}_{14}$ & 680.61 & 703.16 & 295 \\
\hline 26 & 93.0 & 15.48 & (2) 0.12 & $\mathrm{C}_{35} \mathrm{H}_{35} \mathrm{~N}_{3} \mathrm{O}_{15}$ & 737.65 & 760.00 & 252 \\
\hline 27 & 97.1 & 15.04 & (2) 0.32 & $\mathrm{C}_{37} \mathrm{H}_{38} \mathrm{~N}_{4} \mathrm{O}_{16}$ & 794.70 & 817.64 & 294 \\
\hline 28 & 97.6 & 16.04 & (2) 0.35 & $\mathrm{C}_{36} \mathrm{H}_{36} \mathrm{~N}_{4} \mathrm{O}_{16}$ & 780.68 & 803.37 & 294 \\
\hline 29 & 92.0 & 17.57 & (2) 0.36 & $\mathrm{C}_{39} \mathrm{H}_{43} \mathrm{~N}_{3} \mathrm{O}_{15}$ & 793.75 & 816.21 & 297 \\
\hline 30 & 68.1 & 19.33 & (2) 0.27 & $\mathrm{C}_{37} \mathrm{H}_{40} \mathrm{~N}_{2} \mathrm{O}_{14}$ & 736.71 & 759.00 & 297 \\
\hline 32 & 78.9 & - & (3) 0.44 & $\mathrm{C}_{36} \mathrm{H}_{36} \mathrm{~N}_{2} \mathrm{O}_{13}$ & 692.66 & 715.48 & 291 \\
\hline 34 & 76.7 & - & (3) 0.42 & $\mathrm{C}_{42} \mathrm{H}_{43} \mathrm{~N}_{3} \mathrm{O}_{12}$ & 781.78 & 804.42 & 293 \\
\hline 38 & 29.1 & 14.59 & (2) 0.45 & $\mathrm{C}_{37} \mathrm{H}_{40} \mathrm{~N}_{2} \mathrm{O}_{17}$ & 784.71 & 807.41 & 293 \\
\hline 39 & 89.0 & 14.36 & (2) 0.20 & $\mathrm{C}_{37} \mathrm{H}_{40} \mathrm{~N}_{2} \mathrm{O}_{17}$ & 784.71 & 807.39 & 252 \\
\hline 40 & 49.1 & 14.42 & (2) 0.26 & $\mathrm{C}_{37} \mathrm{H}_{40} \mathrm{~N}_{2} \mathrm{O}_{17}$ & 784.71 & 807.02 & 288 \\
\hline
\end{tabular}

TLC: Silica gel $60 \mathrm{~F}_{254}$ (Merck); Solvent systems: (1) $\mathrm{CH}_{2} \mathrm{Cl}_{2}-\mathrm{MeOH}(9: 1)$; (2) toluene - $\mathrm{MeOH}-\mathrm{AcOH}(6: 4: 0.01) ;(3) \mathrm{CH}_{2} \mathrm{Cl} 2-\mathrm{MeOH}_{2}(95: 5)$. HPLC: instrument: Waters 600, UV detection $230 \mathrm{~nm}$; column: Lichrospher RP-8 (4×250 mm/mm; $10 \mu \mathrm{m})$; Injection volume: $20 \mu \mathrm{l}(0.1 \mathrm{mg} / \mathrm{ml})$; Eluents: $\mathrm{A}: \mathrm{CF}_{3} \mathrm{COOH}-\mathrm{H}_{2} \mathrm{O}(\mathrm{pH}$ 2.65), $\mathrm{B}$ : MeCN gradient elution; 0 minute $10 \% \mathrm{~B} \rightarrow 30$ minutes $90 \% \mathrm{~B}$.

MALDI-TOF mass spectra: Bruker Biflex III instrument (the samples were dissolved in DMSO with a 2,5-dihydroxybenzoic acid matrix, concentration: $20 \mathrm{mg} / \mathrm{ml}$, concentration of the components: $5 \mu \mathrm{g} / \mathrm{ml}$, nitrogen laser). Detection of the positive ions was made in the reflecton mode.

The UV spectra were recorded with a Perkin-Elmer $\lambda 11$ instrument ( $\pm 2 \mathrm{~nm}$, absorbance accuracy: $0.001 \AA$ ).

(For some compounds direct ${ }^{13} \mathrm{C}$-NMR spectra were difficult to acquire because of poor solubilty.) Assignments were corroborated with chemical shift prediction of the ACD program [19] and according to our previous work [18].

\section{General Method for the Synthesis of Asymmetric Diamides of Squaric Acid}

The anthracycline antibiotic squaric acid amide esters 7 and $9(0.10 \sim 0.15 \mathrm{mmol})$ were taken up in a $4: 1$ dichloromethane - methanol mixture at room temperature, and if necessary, 1 2 drops of $\mathrm{N}, \mathrm{N}$-dimethylformamide were added for complete dissolution. The apparent $\mathrm{pH}$ of the solution was adjusted to $c a$. 8 by addition of a few drops of triethylamine and then $0.10 \sim 0.15 \mathrm{mmol}$ of the reaction partner carrying a primary or secondary amino group was added. The reaction mixtures were monitored by means of TLC. After completion of the transformation, the mixtures were applied onto the surface of a small amount of Silica gel 60 by evaporation, and chromatographed on Silica gel 60 columns wich were eluted with the eluent systems indicated in Schemes 1 and 2.

The physical characteristics ( $R f$ and $\mathrm{R}_{\mathrm{T}}$ values), and the UV and mass spectral data are shown in Table 1, and the ${ }^{1} \mathrm{H}$ - and ${ }^{13} \mathrm{C}-\mathrm{NMR}$ data are collected in Tables $2 \sim 6$.

\section{In Vitro Antitumour Effect of Daunomycin and Carminomycin Derivatives}

The HL-60 human leukemia cell line was cultured at $37^{\circ} \mathrm{C}$ under $5 \% \mathrm{CO}_{2}$ in RPMI-1640 medium containing $10 \%$ FBS and $2 \mathrm{mM}$ glutamine.

For cytotoxicity studies cells were placed in a 96-well plate with each well containing $5 \times 10^{3}$ cells. After incubation at $37^{\circ} \mathrm{C}$ for 24 hours, the cultured cells were treated with the daunomycin or carminomycin derivatives dissolved in DMSO diluted with serum-free RPMI-1640 medium $(1: 39, \mathrm{v} / \mathrm{v})$ for 3 hours. The compounds were used at the $c=5 \times 10^{-4}$ to $1 \times 10^{-9} \mathrm{M}$ range. In control experiments the cells were treated with DMSO diluted with serum - free medium $(1: 39, \mathrm{v} / \mathrm{v})$ at $37^{\circ} \mathrm{C}$ for 3 hours. After incubation, the cells were washed with serum - free medium three times and serum-containing medium was added to the 
Table $2{ }^{1} \mathrm{H}$ - and ${ }^{13} \mathrm{C}-\mathrm{NMR}$ spectral data of the squaric acid amide esters of anthracycline antibiotics

\begin{tabular}{|c|c|c|c|c|c|c|c|}
\hline \multirow{3}{*}{ Atom number } & \multirow{3}{*}{ Group } & \multicolumn{6}{|c|}{ Compounds } \\
\hline & & \multicolumn{2}{|c|}{$7\left(\mathrm{CDCl}_{3}\right)$} & \multicolumn{2}{|c|}{$8\left(\mathrm{DMSO}+\mathrm{CDCl}_{3}\right)$} & \multicolumn{2}{|c|}{$9\left(\mathrm{CDCl}_{3}+\mathrm{DMSO}=10: 1\right)$} \\
\hline & & $\begin{array}{c}{ }^{1} \mathrm{H}-\mathrm{NMR} \\
\text { (ppm) }\end{array}$ & $\begin{array}{c}{ }^{13} \mathrm{C}-\mathrm{NMR} \\
\text { (ppm) }\end{array}$ & $\begin{array}{c}{ }^{1} \mathrm{H}-\mathrm{NMR} \\
\text { (ppm) }\end{array}$ & $\begin{array}{c}{ }^{13} \text { C-NMR } \\
\text { (ppm) }\end{array}$ & $\begin{array}{c}{ }^{1} \mathrm{H}-\mathrm{NMR} \\
\text { (ppm) }\end{array}$ & $\begin{array}{c}{ }^{13} \mathrm{C}-\mathrm{NMR} \\
(\mathrm{ppm})\end{array}$ \\
\hline 1 & $\mathrm{CH}$ & 8.04 & 120.23 & 7.92 & 120.06 & 7.75 & 119.92 \\
\hline 2 & $\mathrm{CH}$ & 7.80 & 136.2 & 7.742 & 136.4 & 7.65 & 137.51 \\
\hline 3 & $\mathrm{CH}$ & 7.41 & 118.9 & 7.392 & 119.4 & 7.21 & 125.17 \\
\hline 4 & $\mathrm{C}$ & - & 161.5 & - & 161.48 & - & 162.8 \\
\hline $4 a$ & C & - & 121.8 & - & 121.06 & - & 116.31 \\
\hline 5 & C & - & 187.46 & - & 187.33 & - & 190.78 \\
\hline $5 a$ & C & - & $(111.82)^{c}$ & - & $(111.64)^{c}$ & - & $(110.67)^{c}$ \\
\hline 6 & C & - & $(156.16)^{b}$ & - & $(165.65)^{b}$ & - & $(157.12)^{b}$ \\
\hline $6 a$ & C & - & $(134.39)^{a}$ & - & $(134.78)^{a}$ & - & $(134.75)^{\mathrm{a}}$ \\
\hline $6 b$ & $\mathrm{OH}$ & (13.29) & - & 13.2 & - & 12.81 & - \\
\hline 7 & $\mathrm{CH}$ & 5.40 & 68.68 & 5.23 & 68.54 & 5.20 & 68.76 \\
\hline 8 & $\mathrm{CH}_{2}$ & $2.34 / 2.18$ & 35.33 & $2.26 / 2.09$ & 36.25 & $2.25 / 2.04$ & 35.69 \\
\hline 9 & $\mathrm{C}$ & - & 77.07 & - & 76.85 & - & 76.61 \\
\hline 10 & $\mathrm{CH}_{2}$ & $3.27 / 2.98$ & 34.18 & $3.11 / 2.98$ & 34.25 & $3.09 / 2.95$ & 33.91 \\
\hline $10 a$ & $\mathrm{C}^{2}$ & - & $(134.94)^{a}$ & - & $(134.54)^{a}$ & - & $(133.65)^{a}$ \\
\hline 11 & C & - & $(156.62)^{b}$ & - & $(155.91)^{\mathrm{b}}$ & - & $(157.12)^{b}$ \\
\hline $11 a$ & C & - & $(111.95)^{c}$ & - & $(111.76)^{c}$ & - & $(111.51)^{c}$ \\
\hline $11 b$ & $\mathrm{OH}$ & 14.05 & - & 13.97 & - & 13.36 & - \\
\hline 12 & $\mathrm{C}$ & - & 187.14 & - & 187.11 & - & 186.44 \\
\hline $12 a$ & C & - & 135.88 & - & 135.66 & - & 137.44 \\
\hline 13 & $\mathrm{C}$ & - & 212.02 & - & 213.98 & - & 212.07 \\
\hline 14 & $\mathrm{CH}_{3}, \mathrm{CH}_{2}$ & 2.45 & $\left(\mathrm{CH}_{3}\right) 25.18$ & 4.684 & $\left(\mathrm{CH}_{2}\right) 65.45$ & 2.34 & $\left(\mathrm{CH}_{3}\right) 25.07$ \\
\hline 15 & $\mathrm{CH}_{3}$ & 4.10 & 57.1 & 3.95 & 57.15 & - & - \\
\hline $1^{\prime}$ & $\mathrm{CH}$ & 5.61 & 99.45 & 5.44 & 99.83 & 5.42 & 100.5 \\
\hline $2^{\prime}$ & $\mathrm{CH}_{2}$ & $2.04 / 1.86$ & 31.33 & $2.05 / 1.67$ & 30.07 & $2.07 / 1.72$ & 30.81 \\
\hline $3^{\prime}$ & $\mathrm{CH}$ & 4.23 & 51.06 & 3.88 & 51.62 & 3.88 & 51.66 \\
\hline $4^{\prime}$ & $\mathrm{CH}$ & 3.78 & 70.09 & 3.55 & 70.05 & 3.58 & 69.55 \\
\hline $5^{\prime}$ & $\mathrm{CH}$ & 4.17 & 67.85 & 3.99 & 68.22 & 4.05 & 68.2 \\
\hline $6^{\prime}$ & $\mathrm{CH}_{3}$ & 1.37 & 17.08 & 1.22 & 17.45 & 1.24 & 17.38 \\
\hline $7^{\prime}$ & $\mathrm{OH}$ & 3.51 & - & - & - & - & - \\
\hline $8^{\prime}$ & $\mathrm{NH}$ & 6.82 & - & - & - & - & - \\
\hline $1^{\prime \prime}$ & $\mathrm{C}$ & - & 170.22 & - & 172.33 & - & 172.31 \\
\hline $2^{\prime \prime}$ & C & - & 190.03 & - & 189.46 & - & 189.46 \\
\hline $3^{\prime \prime}$ & C & - & 182.99 & - & 183.63 & - & 183.66 \\
\hline $4^{\prime \prime}$ & C & - & 178.46 & - & 177.56 & - & 177.57 \\
\hline $5^{\prime \prime}$ & $\mathrm{CH}_{3}$ & 4.33 & 61.14 & 4.16 & 60.64 & 4.18 & 60.66 \\
\hline
\end{tabular}

Assignments in parenthesis are exchangeable.

cells. After 4 days at $37^{\circ} \mathrm{C}$, the 3-(4,5-dimethylthiazol-2yl)-2,5-diphenyltetrazolium bromide (MTT)-assay [20,21] was carried out. The yellow solution of MTT at a concentration of $2 \mathrm{mg} / \mathrm{ml}$ was added to each well. The purple crystal obtained was dissolved in DMSO and the optical density (OD) of the samples was measured at $\lambda=540 \mathrm{~nm}$ using ELISA Reader (Labsystems MS Reader, Finland). The percent of antitumour effect was calculated using the following equation:

$$
\text { Antitumour effect } \%=\left(1-\mathrm{OD}_{\text {treated }} / \mathrm{OD}_{\text {control }}\right) \times 100 \text {, }
$$
where $\mathrm{OD}_{\text {treated }}$ and $\mathrm{OD}_{\text {control }}$ correspond to the optical 
Table $3{ }^{1} \mathrm{H}$ - and ${ }^{13} \mathrm{C}-\mathrm{NMR}$ spectral data of the asymmetric diamides of squaric acid

\begin{tabular}{|c|c|c|c|c|c|c|c|c|c|}
\hline \multirow{3}{*}{ Atom number } & \multirow{3}{*}{ Group } & \multicolumn{8}{|c|}{ Compounds } \\
\hline & & \multicolumn{2}{|c|}{16 (DMSO) (300 K) } & \multicolumn{2}{|c|}{17 (DMSO) (300 K) } & \multicolumn{2}{|c|}{18 (DMSO) (327 K) } & \multicolumn{2}{|c|}{19 (DMSO) (327 K) } \\
\hline & & $\begin{array}{c}{ }^{1} \mathrm{H}-\mathrm{NMR} \\
\text { (ppm) }\end{array}$ & $\begin{array}{c}{ }^{13} \text { C-NMR } \\
\text { (ppm) }\end{array}$ & $\begin{array}{c}{ }^{1} \mathrm{H}-\mathrm{NMR} \\
\text { (ppm) }\end{array}$ & $\begin{array}{c}{ }^{13} \mathrm{C}-\mathrm{NMR} \\
(\mathrm{ppm})\end{array}$ & $\begin{array}{c}{ }^{1} \mathrm{H}-\mathrm{NMR} \\
\text { (ppm) }\end{array}$ & $\begin{array}{c}{ }^{13} \mathrm{C}-\mathrm{NMR} \\
(\mathrm{ppm})\end{array}$ & $\begin{array}{c}{ }^{1} \mathrm{H}-\mathrm{NMR} \\
\text { (ppm) }\end{array}$ & $\begin{array}{c}{ }^{13} \mathrm{C}-\mathrm{NMR} \\
\text { (ppm) }\end{array}$ \\
\hline 29 & $\mathrm{NH}$ & 7.90 & - & 7.90 & - & 7.42 & - & 7.47 & - \\
\hline 16 & $\mathrm{CH}_{2}$ & 4.73 & 47.34 & 4.74 & 47.34 & 3.48 & 44.10 & 3.49 & 44.12 \\
\hline 17 & $\mathrm{C} / \mathrm{CH}_{2}$ & - & 138.90 & - & 140.22 & 1.511 & 31.54 & 1.512 & 31.56 \\
\hline 18 & $\mathrm{CH} / \mathrm{CH}_{2}$ & 7.39 & 129.05 & - & - & 1.30 & 26.65 & 1.31 & 25.97 \\
\hline 19 & $\mathrm{CH} / \mathrm{CH}_{2}$ & 7.65 & 127.85 & 7.65 & 127.84 & 1.31 & 25.97 & 1.31 & 26.65 \\
\hline 20 & $\mathrm{C} / \mathrm{CH}_{2}$ & - & 140.23 & - & 140.60 & 1.42 & 33.27 & 1.42 & 33.28 \\
\hline 21 & $\mathrm{CH} / \mathrm{CH}_{2}$ & 7.65 & 127.85 & 7.65 & 127.84 & 3.39 & 61.54 & 3.38 & 61.55 \\
\hline 22 & $\mathrm{CH} / \mathrm{OH}$ & 7.39 & 129.05 & - & - & - & - & - & - \\
\hline 23 & C & - & 140.61 & - & - & - & - & - & - \\
\hline 24 & $\mathrm{CH}$ & 7.63 & 127.48 & 7.63 & 127.47 & - & - & - & - \\
\hline 25 & $\mathrm{CH}$ & 7.45 & 129.79 & - & 129.78 & - & - & - & - \\
\hline 26 & $\mathrm{CH}$ & 7.35 & 128.33 & 7.35 & 128.33 & - & - & - & - \\
\hline 27 & $\mathrm{CH}$ & 7.45 & 129.79 & - & 129.78 & - & - & - & - \\
\hline 28 & $\mathrm{CH}$ & 7.63 & 127.48 & 7.63 & 127.47 & - & - & - & - \\
\hline
\end{tabular}

Due to the small changes, in the following no data for the skeletone are given.

Table 4-1 ${ }^{1} \mathrm{H}$ - and ${ }^{13} \mathrm{C}-\mathrm{NMR}$ spectral data of the asymmetric diamides of squaric acid

\begin{tabular}{|c|c|c|c|c|c|}
\hline \multirow{3}{*}{ Atom number } & \multirow{3}{*}{ Group } & \multicolumn{4}{|c|}{ Compounds } \\
\hline & & \multicolumn{2}{|c|}{25 (MeOD) (298 K) } & \multicolumn{2}{|c|}{26 (MeOD) (300 K) } \\
\hline & & ${ }^{1} \mathrm{H}-\mathrm{NMR}(\mathrm{ppm})$ & ${ }^{13} \mathrm{C}-\mathrm{NMR}$ (ppm) & ${ }^{1} \mathrm{H}-\mathrm{NMR}$ (ppm) & ${ }^{13} \mathrm{C}-\mathrm{NMR}$ (ppm) \\
\hline 17 & $\mathrm{CH}_{2}$ & 4.77 & 48.44 & 4.21 & 46.92 \\
\hline 20 & $\mathrm{CH}_{2}$ & - & - & 3.562 & 44.35 \\
\hline
\end{tabular}

Table 4-2 ${ }^{1} \mathrm{H}$ - and ${ }^{13} \mathrm{C}-\mathrm{NMR}$ spectral data of the asymmetric diamides of squaric acid

\begin{tabular}{|c|c|c|c|c|c|}
\hline \multirow{3}{*}{ Atom number } & \multirow{3}{*}{ Group } & \multicolumn{4}{|c|}{ Compounds } \\
\hline & & \multicolumn{2}{|c|}{27 (DMSO) (300 K) } & \multicolumn{2}{|c|}{28 (DMSO) (300 K) } \\
\hline & & ${ }^{1} \mathrm{H}-\mathrm{NMR}(\mathrm{ppm})$ & ${ }^{13} \mathrm{C}-\mathrm{NMR}$ (ppm) & ${ }^{1} \mathrm{H}-\mathrm{NMR}$ (ppm) & ${ }^{13} \mathrm{C}-\mathrm{NMR}$ (ppm) \\
\hline 16 & $\mathrm{NH}$ & 7.60 & - & 7.61 & - \\
\hline 17 & $\mathrm{CH}_{2}$ & 3.45 & 44.47 & 3.46 & 44.35 \\
\hline 18 & $\mathrm{C}$ & - & 173.15 & - & 178.87 \\
\hline 19 & $\mathrm{NH}$ & 8.50 & - & 8.45 & - \\
\hline 20 & $\mathrm{CH}_{2}$ & $4.22 / 4.32$ & 46.85 & $4.23 / 4.28$ & 46.80 \\
\hline 21 & C & - & 171.81 & - & 173.18 \\
\hline 22 & $\mathrm{NH}$ & 8.69 & - & 8.65 & - \\
\hline 23 & $\mathrm{CH}_{2}$ & 3.81 & 43.28 & 3.78 & 43.24 \\
\hline 24 & $\mathrm{C}$ & - & 175.08 & - & 174.36 \\
\hline
\end{tabular}


Table 4-3 ${ }^{1} \mathrm{H}$ - and ${ }^{13} \mathrm{C}-\mathrm{NMR}$ spectral data of the asymmetric diamides of squaric acid

\begin{tabular}{|c|c|c|c|c|c|}
\hline \multirow{3}{*}{ Atom number } & \multirow{3}{*}{ Group } & \multicolumn{4}{|c|}{ Compounds } \\
\hline & & \multicolumn{2}{|c|}{29 (MeOD) (300 K) } & \multicolumn{2}{|c|}{30 (MeOD) (300 K) } \\
\hline & & ${ }^{1} \mathrm{H}-\mathrm{NMR}(\mathrm{ppm})$ & ${ }^{13} \mathrm{C}-\mathrm{NMR}$ (ppm) & ${ }^{1} \mathrm{H}-\mathrm{NMR}$ (ppm) & ${ }^{13} \mathrm{C}-\mathrm{NMR}(\mathrm{ppm})$ \\
\hline 17 & $\mathrm{CH}_{2} / \mathrm{CH}$ & 5.49 & 56.77 & 5.24 & 58.63 \\
\hline 20 & $\mathrm{CH} / \mathrm{CH}_{2}$ & 4.37 & 44.59 & $2.26 / 2.40$ & 45.07 \\
\hline 21 & $\mathrm{CH}_{2} / \mathrm{CH}$ & n.a. & n.a. & 2.39 & 25.89 \\
\hline 22 & $\mathrm{CH} / \mathrm{CH}_{3}$ & 2.40 & 25.38 & 1.63 & 24.13 \\
\hline 23 & $\mathrm{CH}_{3}$ & 1.67 & 23.91 & 1.64 & 24.13 \\
\hline 24 & $\mathrm{CH}_{3}$ & 1.65 & 23.39 & - & - \\
\hline
\end{tabular}

Table $5{ }^{1} \mathrm{H}$ - and ${ }^{13} \mathrm{C}-\mathrm{NMR}$ spectral data of the asymmetric diamides of squaric acid

\begin{tabular}{|c|c|c|c|c|c|}
\hline \multirow{3}{*}{ Atom number } & \multirow{3}{*}{ Group } & \multicolumn{4}{|c|}{ Compounds } \\
\hline & & \multicolumn{2}{|c|}{32 (MeOD) (300 K) } & \multicolumn{2}{|c|}{$34\left(\mathrm{CDCl}_{3}+\mathrm{DMSO}\right)(300 \mathrm{~K})$} \\
\hline & & ${ }^{1} \mathrm{H}-\mathrm{NMR}$ (ppm) & ${ }^{13} \mathrm{C}-\mathrm{NMR}$ (ppm) & ${ }^{1} \mathrm{H}-\mathrm{NMR}$ (ppm) & ${ }^{13} \mathrm{C}-\mathrm{NMR}(\mathrm{ppm})$ \\
\hline 17 & $\mathrm{CH}_{2}$ & 3.74 & 47.54 & n.a. & n.a. \\
\hline 18 & $\mathrm{CH}_{2}$ & 3.73 & 66.84 & 2.62 & 52.83 \\
\hline 20 & $\mathrm{CH}_{2}$ & 3.73 & 66.84 & 2.62 & 52.83 \\
\hline 21 & $\mathrm{CH}_{2}$ & 3.74 & 47.54 & n.a. & n.a. \\
\hline 22 & $\mathrm{CH}_{2}$ & - & - & 3.64 & 62.72 \\
\hline 24 & $\mathrm{CH}$ & - & - & 7.35 & 129.81 \\
\hline 25 & $\mathrm{CH}$ & - & - & 7.31 & 128.79 \\
\hline 27 & $\mathrm{CH}$ & - & - & 7.31 & 128.79 \\
\hline 28 & $\mathrm{CH}$ & - & - & 7.35 & 129.81 \\
\hline
\end{tabular}

Due to deuteration in $\mathrm{MeOD}$, the $\mathrm{OH}$ and $\mathrm{NH}$ signals are not detectable (n.a.).

Table $6{ }^{1} \mathrm{H}$ - and ${ }^{13} \mathrm{C}-\mathrm{NMR}$ spectral data of the asymmetric diamides of squaric acid

\begin{tabular}{|c|c|c|c|c|c|c|c|}
\hline \multirow{3}{*}{ Atom number } & \multirow{3}{*}{ Group } & \multicolumn{6}{|c|}{ Compounds } \\
\hline & & \multicolumn{2}{|c|}{38 (DMSO + MeOD) } & \multicolumn{2}{|c|}{39 (DMSO + MeOD) } & \multicolumn{2}{|c|}{40 (DMSO + MeOD) } \\
\hline & & $\begin{array}{c}{ }^{1} \mathrm{H}-\mathrm{NMR} \\
\text { (ppm) }\end{array}$ & $\begin{array}{c}{ }^{13} \mathrm{C}-\mathrm{NMR} \\
\text { (ppm) }\end{array}$ & $\begin{array}{l}{ }^{1} \mathrm{H}-\mathrm{NMR} \\
\text { (ppm) }\end{array}$ & $\begin{array}{c}{ }^{13} \mathrm{C}-\mathrm{NMR} \\
(\mathrm{ppm})\end{array}$ & $\begin{array}{c}{ }^{1} \mathrm{H}-\mathrm{NMR} \\
\text { (ppm) }\end{array}$ & $\begin{array}{c}{ }^{13} \mathrm{C}-\mathrm{NMR} \\
(\mathrm{ppm})\end{array}$ \\
\hline 17 & $\mathrm{CH}$ & 4.87 & 88.37 & 5.05 & 92.50 & 5.23 & 92.02 \\
\hline 18 & $\mathrm{CH}$ & 3.72 & 64.31 & 3.86 & 59.01 & 4.25 & 55.21 \\
\hline 19 & $\mathrm{CH}$ & 3.19 & 79.06 & 3.52 & 72.28 & 3.84 & 68.93 \\
\hline 20 & $\mathrm{CH}$ & 3.22 & 78.08 & 3.64 & 72.81 & 3.96 & 70.14 \\
\hline 21 & $\mathrm{CH}$ & 3.13 & 70.02 & 3.19 & 71.49 & 3.65 & 63.09 \\
\hline 22 & $\mathrm{CH}_{2}$ & $3.45 / 3.62$ & 61.91 & $3.55 / 3.62$ & 61.91 & 3.74 & 62.10 \\
\hline
\end{tabular}


Table 7 The effect of the new anthracycline derivatives on $\mathrm{HL}-60$ cells in vitro

\begin{tabular}{cr}
\hline Compound number & $\mathrm{IC}_{50}{ }^{*}(\mu \mathrm{M})$ \\
\hline Daunomycin $\cdot \mathrm{HCl}(\underline{\mathbf{1}})$ & $\underline{0.12}$ \\
$\mathbf{1 6}$ & 19.96 \\
$\mathbf{1 7}$ & 1.57 \\
$\mathbf{1 8}$ & 15.65 \\
$\mathbf{1 9}$ & 1.31 \\
$\mathbf{2 5}$ & 2.54 \\
$\mathbf{2 6}$ & 5.70 \\
$\mathbf{2 7}$ & 19.60 \\
$\mathbf{2 8}$ & 2.69 \\
$\mathbf{2 9}$ & 5.75 \\
$\mathbf{3 0}$ & $\underline{0.18}$ \\
$\mathbf{3 2}$ & 29.21 \\
$\mathbf{3 4}$ & 3.39 \\
$\mathbf{3 8}$ & 0.58 \\
$\mathbf{3 9}$ & 0.65 \\
$\mathbf{4 0}$ & $\underline{0.22}$ \\
\hline
\end{tabular}

${ }^{*} \mathrm{C}_{50}$ values were determined as described in the Experimental section and were calculated as an average of three measurements.

densities of the treated cells and the control cells, respectively, at $\lambda=540 \mathrm{~nm}$. The results obtained from in vitro cytotoxicity measurements were analysed using sigmoidal curve fitting.

Acknowledgements The authors thank the Hungarian Academy of Sciences and the National Scientific Research Found (Grant No.: OTKA TO46744, TO42512, T46186, and TO42567) for financial support, Dr. Sándor Kéki (Department of Applied Chemistry, University of Debrecen) for recording the mass spectra, and Dr. József Jekö (ICN Magyarország Rt.) for performing the HPLC measurements. The results included in this paper represent a part of the Diploma Work of Anita Sum, and the PhD Theses of Zsanett Miklán.

\section{References}

1. Arlandini A, Vigevani A, Arcamone F. Interaction of new derivatives of daunorubicin and doxorubicin with DNA. Part II. Farmaco Ed Sci 35: 65-78 (1980)

2. Arcamone F. Doxorubicin Anticancer Antibiotics, Vol. 17. Academic Press, New York (1981)

3. Young CW, Wittes RE. Clinical evaluation of three new anthracyclines: epirubicin, idarubicin and esorubicin. In: Ogawa M, Muggia FM, Rozencweig M (eds.). Adriamycin:
Its Expanding Role in Cancer Treatment. Excerpta Medica, Tokyo, pp. 479-499 (1984)

4. Fuchs EF, Horton D, Weckerle W. Synthesis of 7-O-(2,6dideoxy- $\alpha$-L-lyxo-hexopyranosyl)daunomicinone, a functional analog of daunorubicin. Carbohydrate Res 57: c36-c39 (1977)

5. Sztaricskai F, Menyhárt M, Bognár R. 7-O-(3-Azido-2,3,6trideoxy- $\alpha$ - and $\beta$-L-ribo-hexopyranosyl)carminomycinone: novel analogues of anthracycline antibiotics. Carbohydrate Res 100: c14-c16 (1982)

6. Castillon S, Dessinges A, Faghih R, Lukacs G, Olesker A, Thang TT. Synthesis of 2 -C-fluoro- $\beta$-daunomycin. An example of configurational retention in fluoro-dehydroxylation with diethylaminosulfur trifluoride. J Org Chem 50: 4913-4917 (1985)

7. Priebe W, Neamati N, Perez-Soler R. 3'-Hydroxyesorubicin halogenated at C-2' . J Antibiot 45: 386-393 (1992)

8. Nakai K, Takagi Y, Tsuchiya T. Synthesis and antitumor activity of 7-O-[2,6-dideoxy-2-fluoro-5(trifluoromethyl)- $\alpha$ L-talopyranosyl]-daunomycinone and -adriamycinone. Carbohydrate Res 316: 47-57 (1999)

9. Medgyes G, Pelczer I, Kuszmann J. Carminomycin analogs containing amino-deoxy-L-lyxo-hexofuranosyl derivatives at O-7. Carbohydrate Res 111: 225-237 (1983)

10. Sepelevceva NT, Goldberg LE, Olsufyeva EN, Povarov LS. Study on acute toxicity of some $N$-acyl-derivetive of caminomycin. Antibiotiki 27: 57-61 (1982) (in Russian). Leurubicin: Drugs of Future 18: 116-120 (1993)

11. Olsufyeva EN, Povarov LS, Potapova NP. Synthesis and properties of carminomycin and rubomycin $N$-monoethyl derivatives. Antibiotiki 27: 488-492 (1982) (in Russian)

12. Stefanska B, Dzieduszycka M, Bontemps-Gracz M, Borowski E. Synthesis and antileukemic activity of $\mathrm{N}$ enamine derivatives of sannorubicin, 5-iminodaunorubicin and doxorubicin. J Antibiot 41: 193-198 (1988)

13. Takahashi Y, Kinoshita M, Masuda T, Tatsuta K, Takeuchi T, Umezawa H. 3'-Deamino-3'-morpholino derivatives of daunomycin, adriamycin and carminomycin. J Antibiot 35: 117-118 (1982)

14. Ajito K, Ikeda D, Nosaka C, Komuro K, Kondo S, Takeuchi T. Improved antitumor effects of 3'-deamino-3'-morpholino derivatives of pirarubicin. J Antibiot 43: 1464-1470 (1990)

15. Nakajima S, Kawai H, Komeshima N, Sakakibara M, Tatsuta K, Otake N, Umezawa H. Synthesis and antitumor activity of $4^{\prime}$ - $O$-acylanthracyclines. J Antibiot 45: 374-379 (1992)

16. Menyhárt M, Kövér K, Sztaricskai F. New heterocyclic analogues of anthracycline antibiotics. J Carbohydrate Chem 9: 253-267 (1990)

17. Tietze L, Arlt M, Beller M, Glüsenkamp KH, Jähde E, Rajewsky MF. Squaric acid diethyl ester: a new coupling reagent for the formation of drug biopolimer conjugates. Synthesis of squaric acid ester amides and diamides. Chem Ber 14: 1215-1221 (1991)

18. Tevyashova A, Sztaricskai F, Batta Gy, Herczegh P, Jeney A. 
Formation of squaric acid amides of anthracycline antibiotics. Synthesis and cytotoxic properties. Bioorg Med Chem Lett 14: 4783-4789 (2004)

19. ACD Software

20. Mosman T. Rapid colorimetric assay for cellular growth and survival: Application to proliferation and cytotoxicity assays. J Immunol Methods 65: 55-63 (1983)

21. Slater TF, Sawyer B, Stäuli U. Studies on succinate tetrazolium reductase system III. Points of coupling of four different tetrazolium salts. Biochim Biophys Acta 77: 383393 (1963) 